\title{
Questes
}

vestes Revue pluridisciplinaire d'études médiévales

6 | 2004

La nuit

\section{La nuit : préface}

Andrea Martignoni et Nelly Labere

\section{(2) OpenEdition}

\section{Journals}

\section{Édition électronique}

URL : http://journals.openedition.org/questes/1850

DOI : 10.4000/questes. 1850

ISSN : 2109-9472

\section{Éditeur}

Les Amis de Questes

\section{Édition imprimée}

Date de publication : 15 janvier 2004

Pagination : 5-7

ISSN : 2102-7188

\section{Référence électronique}

Andrea Martignoni et Nelly Labere, «La nuit : préface », Questes [En ligne], 6 | 2004, mis en ligne le 01 janvier 2014, consulté le 25 septembre 2020. URL : http://journals.openedition.org/questes/1850 ; DOI : https://doi.org/10.4000/questes. 1850 


\section{Préface}

Ecoute, ô poète, le cri muet de la nuit. Tes paroles inutiles seront des pas fragiles dans l'obscurité où nulle certitude, sinon l'origine première, te sera dévoilée. Nuit, puissante déesse. Nuit. Toi. Aux ailes noires. Déesse que Zeus lui même redoute, le Vent te courtisa. Alors Eros, d'un œuf d'argent, naquit au sein de l'obscurité... et l'Univers se mit en mouvement.

Enseignements orphiques qui invitent à penser la nuit comme mère matricielle, primordiale, génératrice de tous les principes cosmiques. Qu'il est vertigineux alors de lever le regard dans l'obscurité de la Nuit et de se sentir à nouveau créature, simple créé ! «Au commencement Elohim créa les cieux et la terre. La terre était déserte et vide. Il y avait des ténèbres au-dessus de l'Abîme et l'esprit d'Elohim planait au-dessus des eaux ». Sans nom, elle était déjà là, dense, vide, ténébreuse, avant de rencontrer le Jour, son compagnon, sa négation, son altérité.

Femme ailée - nous raconte Cesare Ripa dans son Iconologia (1593) - revêtue majestueusement d'une longue cape d'azur recouverte d'étoiles, elle tient dans ses bras deux fils. Tous deux dorment. L'un, dans un sommeil éphémère ; l'autre, dans un sommeil éternel.

Nuit, temps du sommeil. Nuit, temps de la mort, nuit sans fin ni horizon. Que serions-nous sans elle? Sans repos, sans rêves, sans mystères et sans angoisses ? 
La lumière finit toujours par nous aveugler, en nous montrant uniquement ce qu'elle veut que l'on voit. Il n'y a que la nuit profonde qui habite les yeux de Tirésias, qui lui permette de voir au-delà, plus loin que l'humain entendement. La vérité ne se dévoile qu'au moment où l'âme s'éveille dans la lumière obscure. «La nuit est sans profils. Elle me touche elle-même et son unité est l'unité mystique du mana. Elle est une profondeur pure sans plans, sans surfaces, sans distance d'elle à moi », écrit Maurice Merleau-Ponty. Grande métaphore, la nuit, mère créatrice, muse inépuisable. Se laisse-t-elle approcher, penser, dire ? Se laisse-t-elle traverser laissant indemnes ses téméraires voyageurs? La nuit avant d'être un espace-temps est avant tout symbole. S'ouvre alors le vertige, prêt à engloutir ceux qui la défient. Mais le voyage n'écoute guère le danger. Sé-duction, il nous invite à la navigation, au départ incessant. Sirène, partons au bout de la nuit ! Place à l'égarement, à l'abandon du trop de certitudes qui nous emprisonnent dans la voix de la raison. Que les humbles perdent leur chemin pour en trouver d'autres. Seul importe le voyage. Le port, lui, immobile miroir, n'est qu'illusion.

En littérature, comme en histoire ainsi que dans ses présences iconographiques, la nuit semble surgir d'un combat, d'une dialectique, d'une tension entre la lumière et l'obscurité. Sa surface n'est point lisse, elle se prête à mille interrogations. Eloge de la transgression, poésie du silence, temps de prières salutaires et de tentations maléfiques, drap luisant pour tout amour impossible, temps de la bonne mort ou temps du re-mort. La nuit est tout cela. Source 
d'inspiration pour les poètes, pour les amants, pour les diables et les transgresseurs. La nuit est l'autre qui nous guette, qui nous attend au-delà du dernier rayon de soleil solitaire.

A nous alors ce défi. Celui de réfléchir à cette autre présence qu'est la nuit. Au poète Novalis de chanter ce mystère qui semble triompher sur le temps: «soudain je sentis se rompre le lien de la naissance... Ferveur des nuits, sommeil sacré... Sainte, ineffable, mystérieuse nuit. Plus divins que les étoiles scintillantes, nous semblent les yeux infinis que la Nuit a ouverts en nous. Leur regard porte bien au-delà des astres... emplissant d'une volupté indicible l'espace qui est au-dessus de l'espace ».

Si nuit médiévale il y a, notre vagabondage en elle n'aura pas été vain. 